薬学におけるセルフメディケーションと品質保証に関する教育 〜アンケート調査結果から〜

$$
\text { 小松かつ子 }
$$

\title{
Current Status of Pharmaceutical Education for Self-medication and Quality Assurance: Based on Evaluation from the Questionnaire
}

\author{
Katsuko Komatsu \\ Institute of Natural Medicine, University of Toyama; 2630 Sugitani, Toyama 930-0194, Japan.
}

(Received September 28, 2020)

\begin{abstract}
The role of pharmaceutical education in primary health care for self-medication needs recognition. Hence, we conducted a survey on quality assurance of foods/pharmaceuticals at 75 pharmaceutical schools in Japan, as part of a project for the Subcommittee of Clinical Pharmacy and Pharmaceutical Sciences, Science Council of Japan. The set of questions in the survey focused on two subjects, one set was related to the lectures on "foods with health claims" (I) and the other set was on quality assessment of pharmaceuticals (II). For each subject, we asked whether there were lectures on these subjects and whether all items were covered. We also asked for the title of lectures, major field of experts in charge, and class standing. We received a response from 60 schools. Thirty-two schools had lectures on subject I in which all seven items were covered. However, "regulatory sciences", "borderline of pharmaceuticals to non-pharmaceuticals", and "quality assurance of foods" were not explained in 22, 12, and 15 schools, respectively. Twenty-six schools had lectures on subject II in which all six items were covered. However, "definition of quality", "quality assurance", "classification of pharmaceuticals", and "Chemistry, Manufacturing and Control" were not explained in 12, 11,12 , and 29 schools, respectively. The high rate of insufficient explanation for some of the items in subject I and II may be due to the lack of description about them in the "Model Core Curriculum for Pharmacy Education". We conclude that including these items in the curriculum can have important implications for pharmaceutical education.
\end{abstract}

Key words _ education; self-medication; foods with health claims; quality assurance; questionnaire

\section{1. アンケート調査の背景}

超高齢化社会を迎えたわが国では，国民健康づく り運動として「健康寿命の延伸」,「生活習慣病の発 症・重症化の予防」の政策が打ち出され，地域包括 ケアによる健康サポートが進められている。この実 現に向けて薬学部においても医療システムの中での プライマリケア，セルフメディケーション等に関連 した教育研究を行っているところである.この中の 医療系薬学分野には，1つの重点領域として，一般 用医薬品として用いられる生薬・漢方製剤や，保健 機能食品（特定保健食品, 栄養補助食品, 機能性表 示食品)，健康食品，サプリメント等に関する教育 研究が含まれている. しかし，医薬品以外について

富山大学和漢医薬学総合研究所（干930-0194 富山市杉 谷 2630)

e-mail: katsukok@inm.u-toyama.ac.jp

本総説は, 日本薬学会第 140 年会シンポジウムS11 で 発表した内容を中心に記述したものである.
は教員及び薬学部生の意識は低いことが懸念され， それらの法制度や研究の実態については知られてい ないのが現状である.さらに，社会的要請の強い医 薬品の品質保証についても教育状況が不明である. そこで, 日本学術会議薬学委員会医療系薬学分科会 (24 期) では, プライマリケアやセルフメディケー ションに対する薬学の立ち位置と薬学教育の役割を 再認識することを目的として，2019 年 6 月 28 日-9 月 17 日に全国薬科大学長・薬学部長のご理解とご 協力の下, 全国の薬学部を設置する 75 大学を対象 に「食品・医薬品の品質保証に関する薬学教育の実 態調査」をアンケート形式で実施した.

アンケートでは 2 つ課題に対する講義，すなわ ち保健機能食品, 健康食品, 食薬区分等に関する講 義及び医薬品の品質保証に関する講義についてそれ ぞれ，講義の有無，講義で下記の重要項目 $(\mathrm{A})-$ (M)が説明されているか, 説明されている場合は項 目毎に受講対象学生の学年, 講義の科目名と担当教 
Table 1. Questionnaire Items for Pharmaceutical Education Concerning Quality Assurance of Foods/Pharmaceuticals

I Q1. Are lectures delivered on Subject I-concerning foods with health claims, etc.?

Q2. Answer the following questions about the lectures on Subject I.

(1) Students' school year, (2) Title of lecture, (3) Major field of experts in charge, (4) Presence or absence of explanation on the following 7 critical items

(A) Regulatory science, (B) Distinguishing features of pharmaceuticals, foods with health claims and so-called "health food", (C) Borderline of pharmaceuticals to non-pharmaceuticals, (D) Foods for specified health uses, (E) Foods with nutrient function claims, (F) Foods with function claims, (G) Quality assurance of foods.

Q3. Are lectures on any of the following topics planned in the future: regulatory science, foods with health claims, so-called "health food," and borderline of pharmaceuticals to non-pharmaceuticals? If there is, describe the lecture title and its content.

II Q4. Are lectures delivered on Subject II-concerning quality assurance of pharmaceuticals?

Q5. Answer the following questions about the lectures on Subject II.

(1) Students' school year, (2) Title of lecture, (3) Major field of experts in charge, (4) Presence or absence of explanation on the following 6 critical items

(H) Definition of quality, (I) Quality assurance, (J) Classification of pharmaceuticals, (K) Marketing authorization process of pharmaceuticals, (L) International Council for Harmonisation of Technical Requirements for Pharmaceuticals for Human Use (ICH), (M) Chemistry, Manufacturing and Control (CMC).

Q6. Is a lecture on the topic of quality assurance of pharmaceuticals planned for the future? If there is, describe the lecture title and its content.

員の専門分野，及び今後の講義計画について質問し た (Table 1).

I ）（A）レギュラトリーサイエンス，（B）医薬 品, 保健機能食品及び健康食品の区別点，(C) 食薬区分，（D）特定保健用食品，（E）栄養補助 食品, (F) 機能性表示食品, (G）食品の品質保 証；II）（H）品質の定義，（I）品質保証とは， (J) 医薬品の区分 (医療用医薬品, 一般用医薬品, 医薬部外品),（K）医薬品の承認申請，（L) ICH (医薬品規制調和国際会議)，（M） CMC（化学, 製造，管理）

回答の処理では, 重要項目別に, 講義科目が属す る学系を日本薬学会の一般学術発表分類に準じて整 理した。また，受講学生は，6 年制課程では 1-2 回 生（低学年），3 回生-5 回生前半（病院・薬局で害 務実習を行う前）及び 5 回生後半-6 回生（実習後） に分け，4年制課程では 1-2 回生と 3-4 回生（高学 年）に分けて整理した.

\section{2. アンケート調査結果の概略}

回答は 60 校（回答率 $80 \%$ ） からあり，そのうち 16 校で薬学教育 6 年制課程のほかに, 4 年制課程の 状況についても回答があつた。保健機能食品, 健康 食品, 食薬区分等に関する講義 $(\mathrm{I})$ ，医薬品の品 質保証に関する講義（II）を実施している大学はと
もに 58 校であった。講義を行っていない 2 校は 1 校のみ重複し，I については今後も実施計画がな かったが，Iはは計画されていた（Table 2).

I， II を担当する科目の集計結果から，I は化学 系, 物理系, 環境・衛生系, 医療系, 教育系・その 他, II は化学系, 物理系, 生物系, 医療系, 教育 系・その他の科目で講義されていることがわかり， 大半が広義の医療系薬学（健康科学系, 薬剤学系, 薬理学系, 衛生化学系, 医療薬学系, 社会薬学 系)1に含まれていた（Table 3)。

\section{2-1. 保健機能食品, 健康食品, 食薬区分等に関} する講義 6 年生課程では，保健機能食品，健康 食品, 食薬区分等に関する講義が実施されている 60 校中 32 校 $(53.3 \%)$ で重要項目のすべてが説明 されていた。しかし，講義が実施されていない 2 校 を含め,（A）レギュラトリーサイエンスは 22 校,

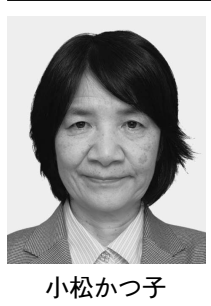

富山大学薬学部卒業, 富山医科薬科大 学大学院薬学研究科博士課程を修了し, 1988 年から同大学和漢薬研究所に勤務, 2004 年同教授, 2019 年和漢医薬学総合 研究所長. 生薬学を専門とし, アジア の薬用植物の多様性解析とそれに基づ <生薬の標準化研究に従事. 和漢医薬 学会理事長, 日本生薬学会会長を務め る. 日本学術会議連携会員. 
Table 2. Survey Results

\begin{tabular}{|c|c|c|c|c|}
\hline \multirow{2}{*}{$\begin{array}{c}\text { Response } \\
\text { Rate }\end{array}$} & \multirow{2}{*}{$\begin{array}{c}\text { No. of schools: } \\
\text { Responded / All }\end{array}$} & \multicolumn{3}{|c|}{ School Category (SC) } \\
\cline { 3 - 5 } & National & Municipal & Private \\
\hline $\mathbf{8 0} \%$ & $\mathbf{6 0} / 75$ & $\mathbf{1 2 / 1 4}$ & $\mathbf{4} / 4$ & $\mathbf{4 4} / 57$ \\
\hline
\end{tabular}

\begin{tabular}{|l|c|c|c|c|}
\hline Q1 \& Q3 - Lectures on foods with health claims, etc. & \multicolumn{1}{c|}{ (No. of schools) } \\
\hline \multicolumn{1}{|c|}{ SC } & National & Municipal & Private & Total \\
\hline Lectures offered (a) & 11 & 4 & 43 & 58 \\
\hline No lectures offered (b) & 1 & 0 & 1 & 2 \\
\hline $\begin{array}{c}\text { Future lectures planned } \\
\text { (a*, b) }\end{array}$ & $\mathbf{( 1 , 0 )}$ & $\mathbf{( 0 , 0 )}$ & $\mathbf{( 3 , 0 )}$ & $(4,0)$ \\
\hline
\end{tabular}

\begin{tabular}{|c|c|c|c|c|}
\hline SC & National & Municipal & Private & Total \\
\hline Lectures offered (a) & 11 & 4 & 43 & 58 \\
\hline No lectures offered (b) & 1 & 0 & 1 & 2 \\
\hline $\begin{array}{l}\text { Future lectures planned } \\
\left(a^{*}, b\right)\end{array}$ & $(1,1)$ & $(0,0)$ & $(1,1)$ & $(2,2)$ \\
\hline
\end{tabular}

* indicates plans to increase contents by schools already offering a lecture.

Table 3. Lecture Titles Covering Seven Critical Items of Subject I (e.g., foods with health claims) and Six Critical Items of Subject II (quality assurance of pharmaceuticals) and Their Classification Categories*

Subject I The lectures on foods with health claims, etc. covering seven items (A-G)

化学系 : 生薬学, 薬用植物学, 天然物薬学, 天然薬学; 漢方薬学, 漢方薬学概論 (生薬学教員担当)

物理系：品質管理入門（特別講義）

環境・衛生系 : 衛生薬学 I-IV; 衛生化学 I, II ; 食品衛生学; 栄養学, 栄養と健康, 栄養化学, 栄養生理学 ; 食品機能学, 機 能性食品学；食品安全性学

医療系 : セルフメディケーション学 ; 医薬品情報学 ; レギュラトリーサイエンス ; コミュニティファーマシー, 社会薬学 ;

一般用医薬品学, OTC 医薬品概論 ; プライマリーケア ; 臨床栄養学, 栄養管理学

教育系・その他：薬事関連法規・制度（薬事衛生法規，薬事法規）

オムニバス形式他 : 薬学概論

Subject II The lectures on quality assurance of pharmaceuticals covering six items $(\mathrm{H}-\mathrm{M})$

化学系: 天然物薬学, 生薬学, 薬用植物学

物理系：製剤学, 応用製剤学; 薬品分析学, 薬品分析化学

生物系：医薬品開発学, 医薬品開発論（薬理学, 微生物学, 分子生物学教員担当）

医療系: 医薬品情報学, 医薬品情報管理学, 医薬品情報評価学; 医薬品開発学, 医薬品開発論; 製剂学, 製剤設計学, 製剤 材料学, 製剤工学; レギュラトリーサイエンス; 医薬品安全性評価学, 医薬品評価と安全性監視, 医薬品安全性 学, 医薬品管理 ; 医療薬学, 医療薬学総論; セルフメディケーション学, 薬学健康管理学

教育系・その他：薬事関連法規

オムニバス形式他：医薬開発論，実践医薬開発概論

* Based on the classification system of the Pharmaceutical Society of Japan.

（C）食薬区分は 12 校，（G）食品の品質保証は 15 校でそれらの内容が説明されていなかった（Fig. 1). 講義は，全項目で環境・衛生系薬学，続いて医 療系薬学の科目で説明される場合が多かつた（6896\%)。他の項目に比べて（A）では教育系薬学・ その他, （B）医薬品, 保健機能食品及び健康食品 の区別点と（C）では化学系薬学で説明される場合
がやや多く，（G）はもつぱら環境・衛生系薬学で 説明されていた (Fig. 2). 各項目は 1 科目又は 2 科目で説明される場合が多かつたが，（B），(D)， (E)，（F）では 3-5 科目でも説明されていた（Fig. 3). 教育の時期は，実務実習前までに教えられるこ とが多かつた（Fig. 2).

4 年制課程では, 16 校中 9 校ですべての重要項目 


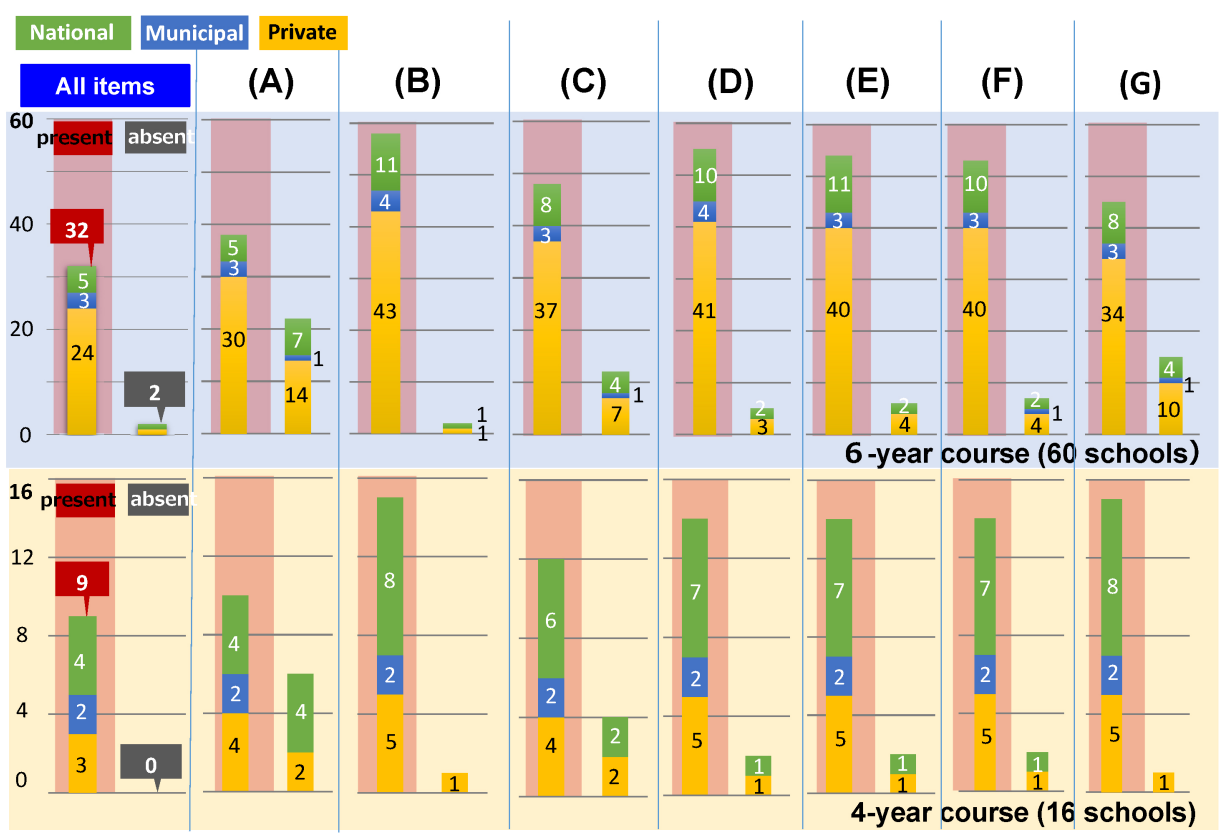

Fig. 1. Education on Subject I concerning Foods with Health Claims, etc.: Presence or Absence of Explanation on Seven Critical Items

(A) Regulatory science; (B) Distinguishing features of pharmaceuticals, foods with health claims and so-called "health food"; (C) Borderline of pharmaceuticals to non-pharmaceuticals; (D) Foods for specified health uses; (E) Foods with nutrient function claims; (F) Foods with function claims; (G) Quality assurance of foods. (Color figure can be accessed on the online version.)

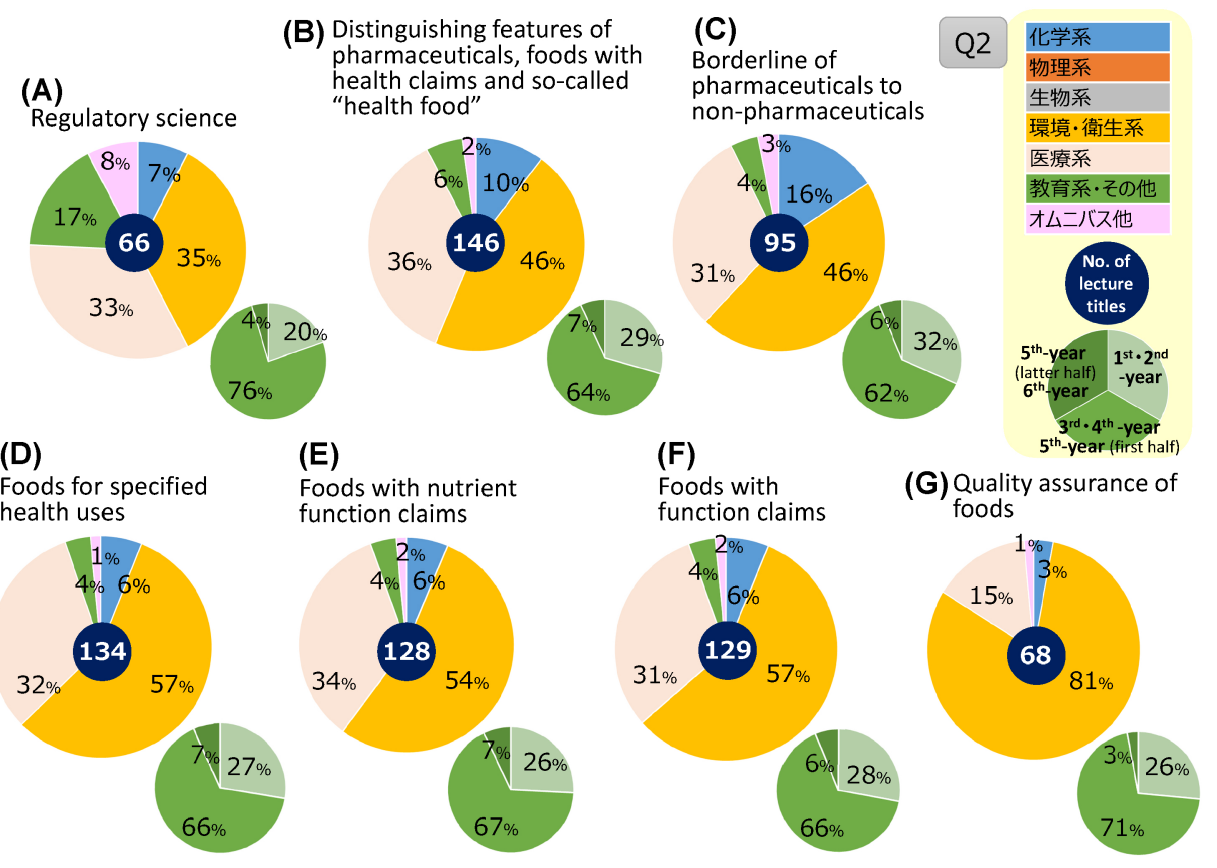

Fig. 2. Classification Categories of Lecture Titles Covering Each Item of Subject I, and Students' School Year〈6-Year Course〉 (Color figure can be accessed on the online version.)

が説明されていたが，（A）は 6 校，（C）は 4 校で 説明されていなかった（Fig. 1)。重要項目は環境・ 衛生系薬学の科目で説明される場合が多かったが, 6 年制課程に比べ化学系薬学で説明される割合が増
え，また 1 科目で説明される割合が増えた（Figs. 4 and 5)。（B)，（C）は低学年，それ以外は高学年で 教えられる場合がやや多かった (Fig. 4).

2-2. 医薬品の品質保証に関する講義 6 年生 
(A)

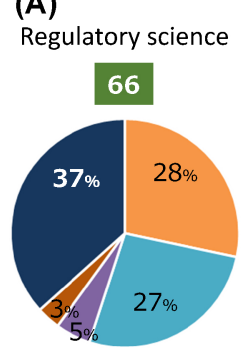

(D)

Foods for specified health uses

134

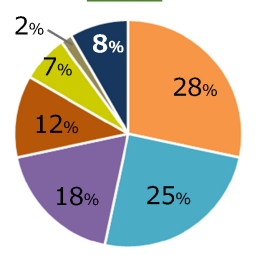

(B) Distinguishing features of pharmaceuticals, foods with health claims and so-called "health food" 146

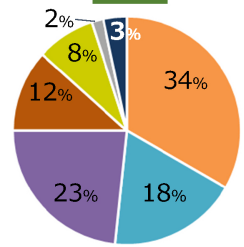

(E)

Foods with nutrient function claims

$$
128
$$

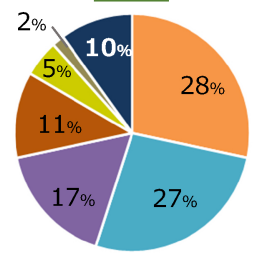

(C)

Borderline of

pharmaceuticals to

non-pharmaceuticals 95

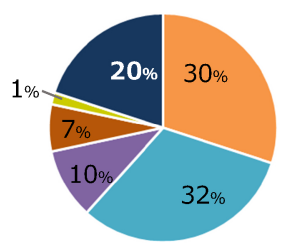

(F)

Foods with function claims

129

(G)

Quality assurance of

foods

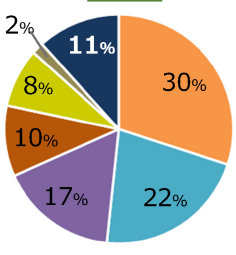

Q2

Total number

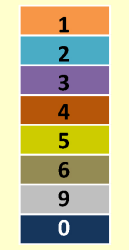

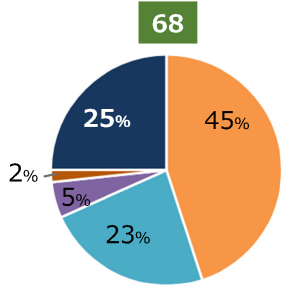

Fig. 3. Number of Lecture Titles Covering Each Item of Subject I 〈6-Year Course (Color figure can be accessed on the online version.) 


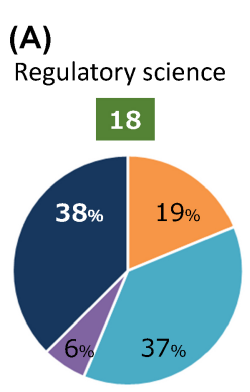

(D)

Foods for specified health uses

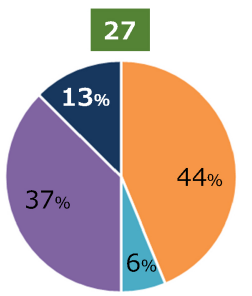

(B) Distinguishing features of pharmaceuticals, foods with health claims and so-called "health food"
(C)

Borderline of pharmaceuticals to non-pharmaceuticals

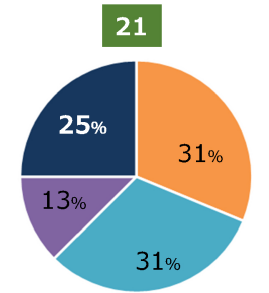

(F)

(E) Foods with nutrient function claims 26

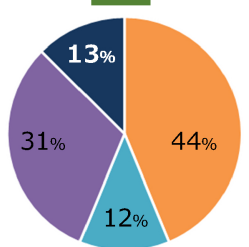

Foods with function claims

27

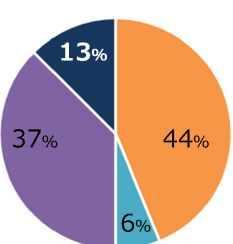

\section{Q2}

Total number

Fig. 5. Number of Lecture Titles Covering Each Item of Subject I 〈4-Year Course〉 (Color figure can be accessed on the online version.)

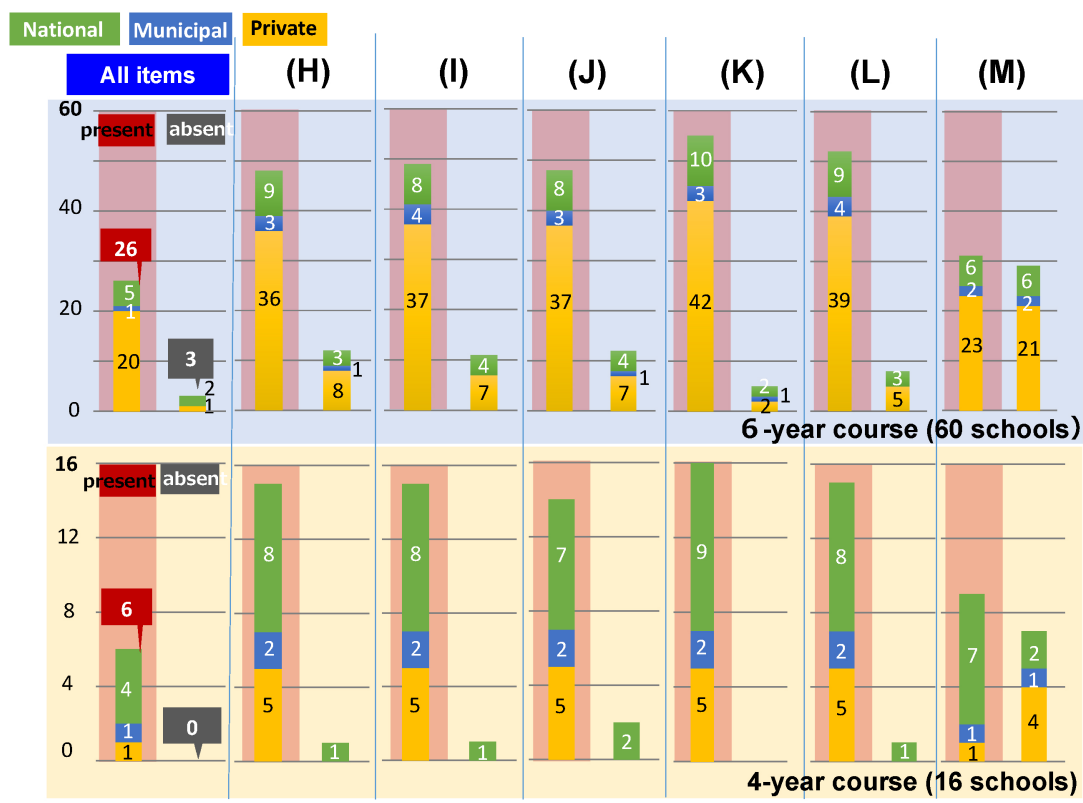

Fig. 6. Education on Subject II concerning Quality Assurance of Pharmaceuticals: Presence or Absence of Explanation on Six Critical Items

(H) Definition of quality; (I) Quality assurance; (J) Classification of pharmaceuticals; (K) Marketing authorization process of pharmaceuticals; (L) International Council for Harmonisation of Technical Requirements for Pharmaceuticals for Human Use (ICH); (M) Chemistry, Manufacturing and Control (CMC) . (Color figure can be accessed on the online version.)

かつた (Fig. 7). 各項目は 1，2 科目で説明される 場合が多く，また（M）以外では 3，4 科目でも説 明されていた（Fig. 8)。科目の約 70\%は実務実習 前に教えられ，I に比べると実習後に教えられる割 合が増えた（Fig. 7).
4 年制課程では, 16 校中 6 校ですべての重要項目 が説明されていたが，（M）は７校で教えられてい なかった（Fig. 6）。重要項目は医療系薬学で説明 される場合が多かつたが，6年制課程に比べて教育 系薬学・その他及び化学系薬学で説明される割合が 
(H) Definition of quality

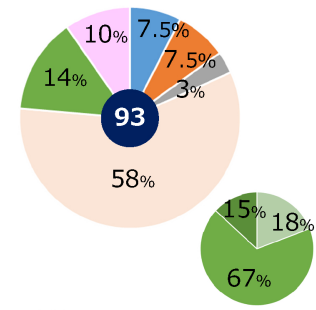

(K)

Marketing authorization process of pharmaceuticals

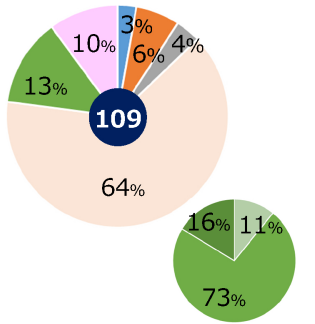

(I) Quality assurance

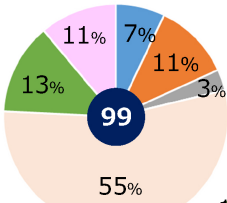

(L) $\mathrm{ICH}^{*}$

(M) CMC*

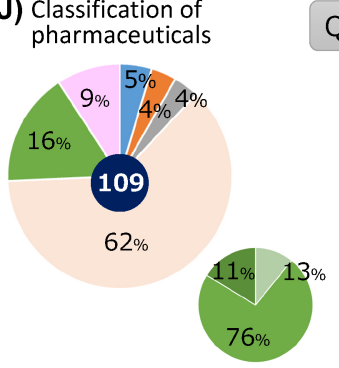

Q5

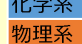

生物系

環境·衛生系

医療系

教育系·その他

オムニバス他

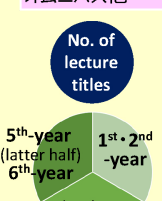

$3^{\text {rd }} \cdot 4^{\text {th }}$-year
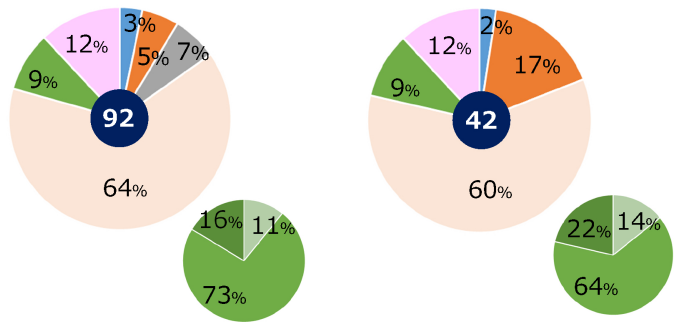

Fig. 7. Classification Categories of Lecture Titles Covering Each Item of Subject II, and Students' School Year〈6-Year Course〉 *ICH: International Council for Harmonisation of Technical Requirements for Pharmaceuticals for Human Use; CMC: Chemistry, Manufacturing and Control. (Color figure can be accessed on the online version.)

(H) Definition of quality

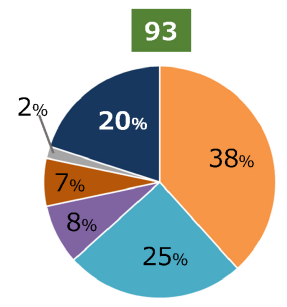

(K) Marketing authorization process of pharmaceuticals

\section{9}

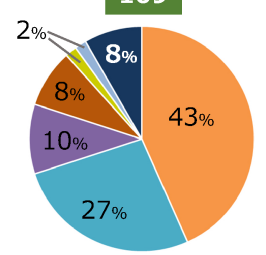

(I) Quality assurance

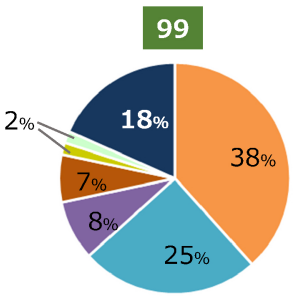

(L) $\mathrm{ICH}^{*}$

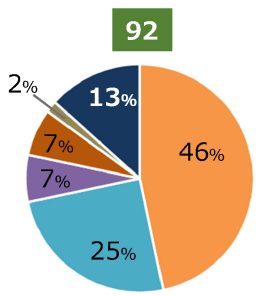

(J) Classification of pharmaceuticals 109

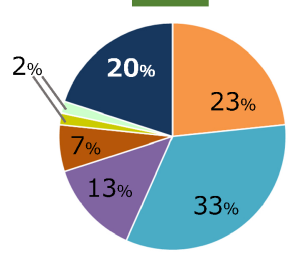

(M) $\mathrm{CMC}^{*}$

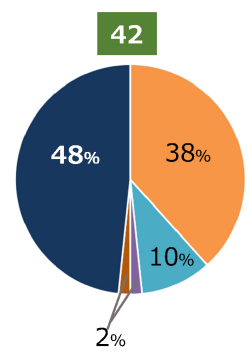

Q5

Total number

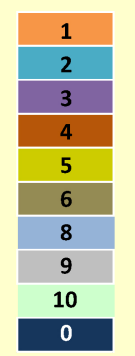

Fig. 8. Number of Lecture Titles Covering Each Item of Subject II 〈6-Year Course

*ICH: International Council for Harmonisation of Technical Requirements for Pharmaceuticals for Human Use; CMC: Chemistry, Manufacturing and Control. (Color figure can be accessed on the online version.)

増えた。また 6 年制課程と同様に物理系薬学で説明 される場合が加わつた。科目の $70 \%$ 以上が高学年 で教えられ，また 1 科目で説明される割合が増えた (Figs. 9 and 10).
3. 薬学教育モデル・コアカリキュラム等との関 連性

6 年制課程の薬学教育は, その 7 割を文部科学省 の薬学教育モデル・コアカリキュラム（以下，モデ ル・コアカリ）に示された内容に従って実施され 


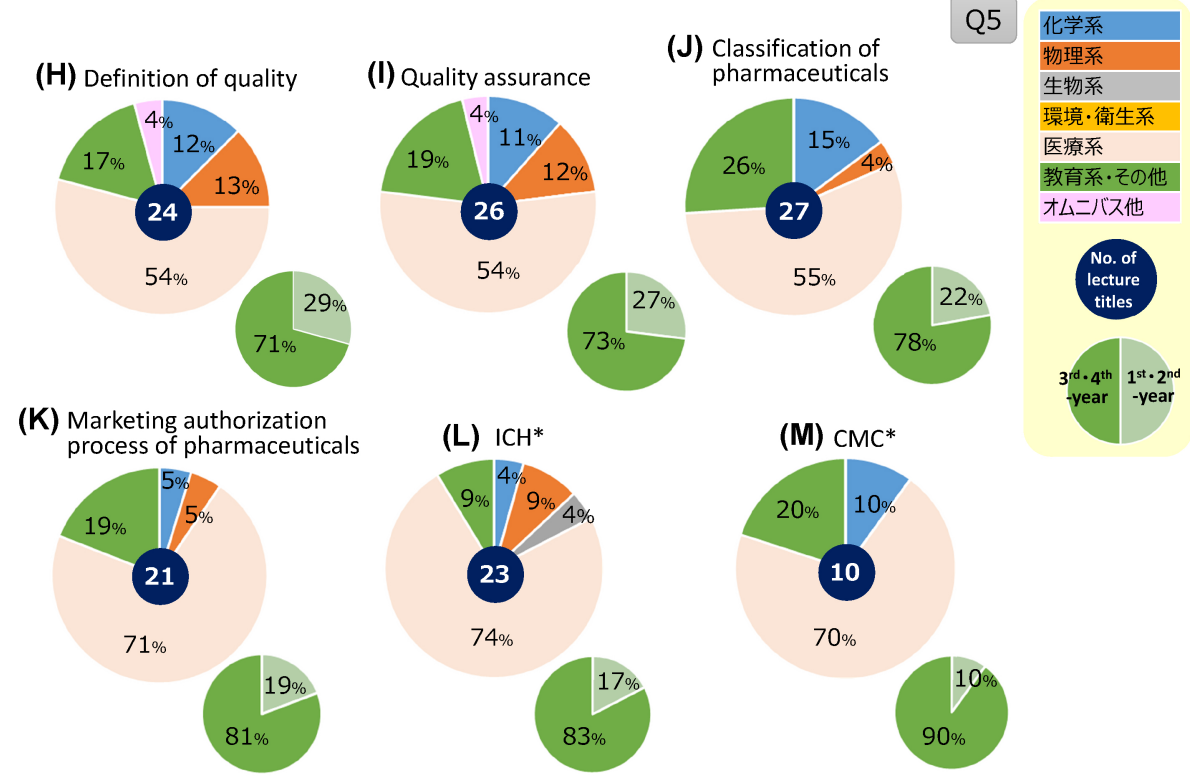

Fig. 9. Classification Categories of Lecture Titles Covering Each Item of Subject II, and Students' School Year 〈4-Year Course〉 *ICH: International Council for Harmonisation of Technical Requirements for Pharmaceuticals for Human Use; CMC: Chemistry, Manufacturing and Control. (Color figure can be accessed on the online version.)

(H) Definition of quality

24

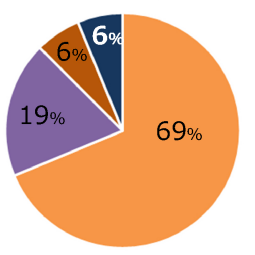

(K) Marketing authorization process of pharmaceuticals

21

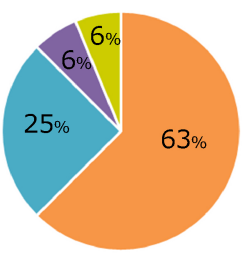

(I) Quality assurance

26

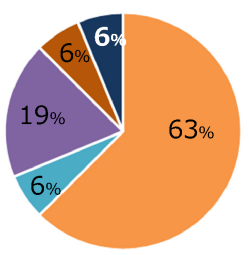

(L) $\mathrm{ICH}^{*}$

23

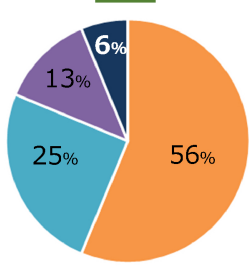

(J) Classification of pharmaceuticals

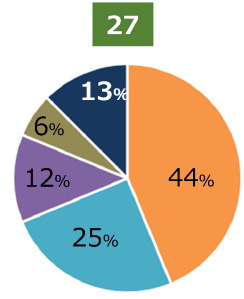

(M) $\mathrm{CMC}^{*}$

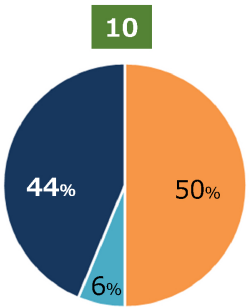

Fig. 10. Number of Lecture Titles Covering Each Item of Subject II 〈4-Year Course

*ICH: International Council for Harmonisation of Technical Requirements for Pharmaceuticals for Human Use; CMC: Chemistry, Manufacturing and Control. (Color figure can be accessed on the online version.)

る.また，残りの 3 割程度は大学独自のカリキュラ ムにより行われ，その参考として薬学アドバンスト 教育ガイドライン（以下，アドバンスト教育ガイド ライン）が示されている. 今回のアンケート調査結 果は, モデル・コアカリの達成目標やアドバンスト 教育ガイドラインの記載に関連すると考えられたこ

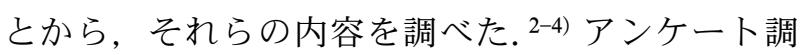

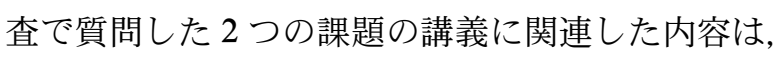
$\mathrm{B}$ 薬学と社会, $\mathrm{C}$ 薬学基礎-C5 自然が生み出す薬物, $\mathrm{D}$ 衛生薬学-D1 健康, $\mathrm{E}$ 医療薬学-E2 薬理・病態 • 薬物治療；E3 薬物治療に役立つ情報；E5 製剂化の サイエンス，F薬学臨床にみられた。 
(A) レギュラトリーサイエンス

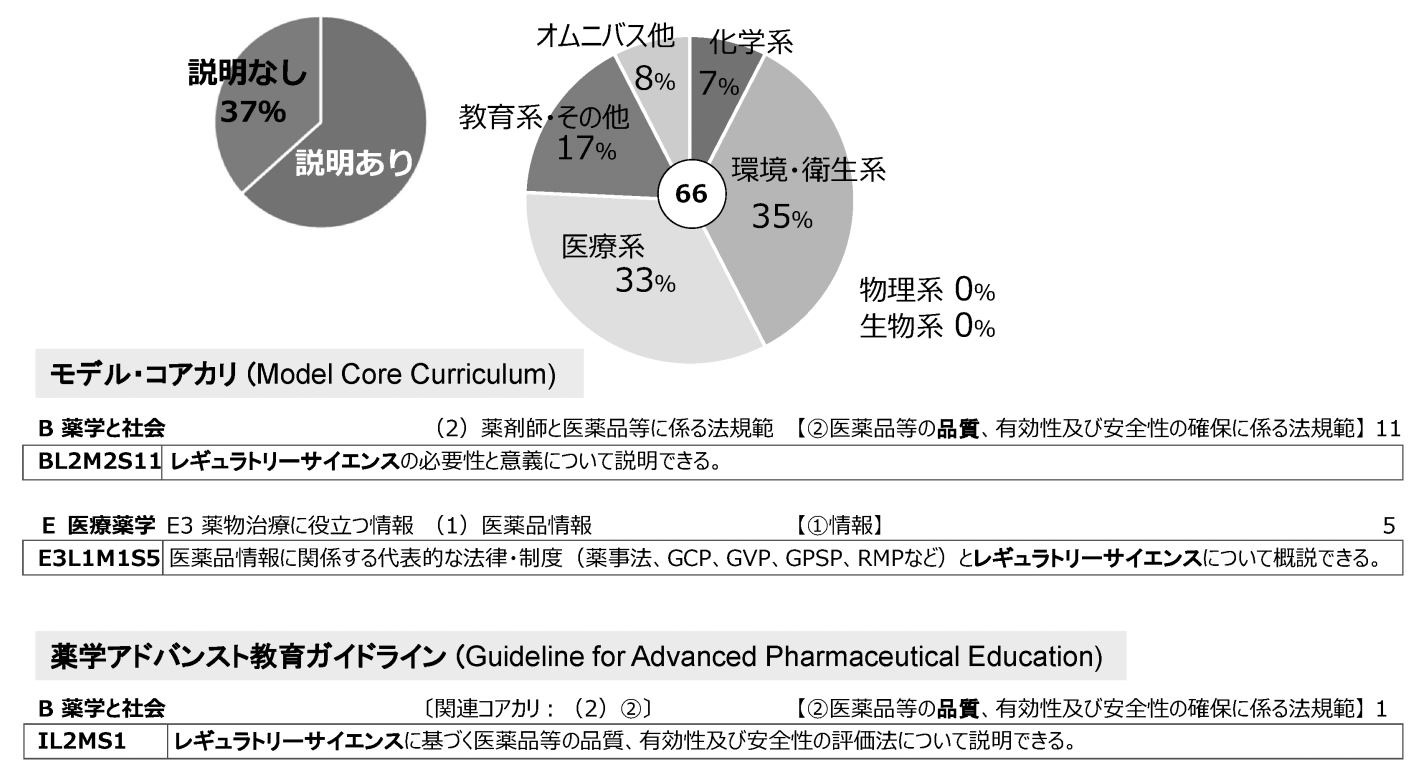

Fig. 11. Relevance of the Survey Results to Contents of the Model Core Curriculum for Pharmaceutical Education 1 (A) Regulatory science.

3-1. 保健機能食品, 健康食品, 食薬区分等に関 する重要項目（A）レギュラトリーサイエンス は，モデル・コアカリの B (2) 薬剤師と医薬品等 に係る法規範【(2)医薬品等の品質, 有効性及び安全 性の確保に係る法規範】の 11 項や E3（1）医薬品 情報【(1)情報】の 5 項において，必要性と意義が説 明でき，内容が概説できることが目標になってい る. しかし今回の調査の結果, $36.7 \%$ の大学で説明 されておらず，今後の改善が強く望まれる（Fig. 11). (B)-(G) の内容は, プライマリケアやセルフ メディケーションの実践上, 習得すべき知識であ り, また地域社会への説明義務が求められている内 容でもあるため, これらを学ぶことは薬学生にとつ て必要である。しかし，（C）食薬区分及び（G）食 品の品質保証は, モデル・コアカリ及びアドバンス ト教育ガイドラインに記載がなく，これら 2 項目に 関してそれぞれ $20 \% ， 25 \%$ の大学で説明されてい なかったことはこれを反映した結果であると考えら れる（Fig. 12)。食薬区分は，薬機法で取り締まる 医薬品と, 食品衛生法で取り締まる食品を区別する 法規範であり，また保健機能食品の品質は医薬品に 準ずるべきものと考えられることから，(C) と (G) についてはモデル・コアカリへの収載も視野に入れ ながら，（B）医薬品, 保健機能食品及び健康食品 の区別点に関連して説明されることが求められる.
3-2. 医薬品の品質保証に関する重要項目

(H) 品質の定義は，モデル・コアカリの B (2) (2)の 7 項の「医薬品等の取扱いに関する ‘医薬品, 医療機器等の品質, 有効性及び安全性の確保等に関 する法律' の規定について説明できる」及び，間接 的ではあるが，C5（1）薬になる動植鉱物【(4)生薬 の同定と品質評価】の 1 項や，E3（1）医薬品情報 【(7)医薬品の比較・評価】の 3 項, さらに E5 (2) 製剂設計【(3)生物学的同等性】の 1 項に関連して, 理解しておくべき目標となっていた（Fig. 13）。し かし, 今回の調査結果では $20 \%$ の大学で「品質の 定義」が説明されていなかったことから，改善を促 したい.（I）「品質保証とは」については，品質の 定義と同時に講義されるべき内容であるが，モデ ル・コアカリにはこれに該当する目標がなかった.

アドバンスト教育ガイドラインでは，B(2)の 1 項に 「レギュラトリーサイエンスに基づく医薬品等の品 質，有効性及び安全性の評価法について説明でき る」，E5【(1)製剤化】の 4 項に「製剤の物性值から, 製剂の品質を判定できる（知識・技能）」などがあ り, 品質の評価法や判定などの実施方法の習得が目 標とされているのみで，概念の習得については述べ られていない (Fig. 13)。このことが 18.3\%の大学 で講義がなかった原因であるものと考えられ，「品 質保証の概念，必要性と意義について説明できる」 


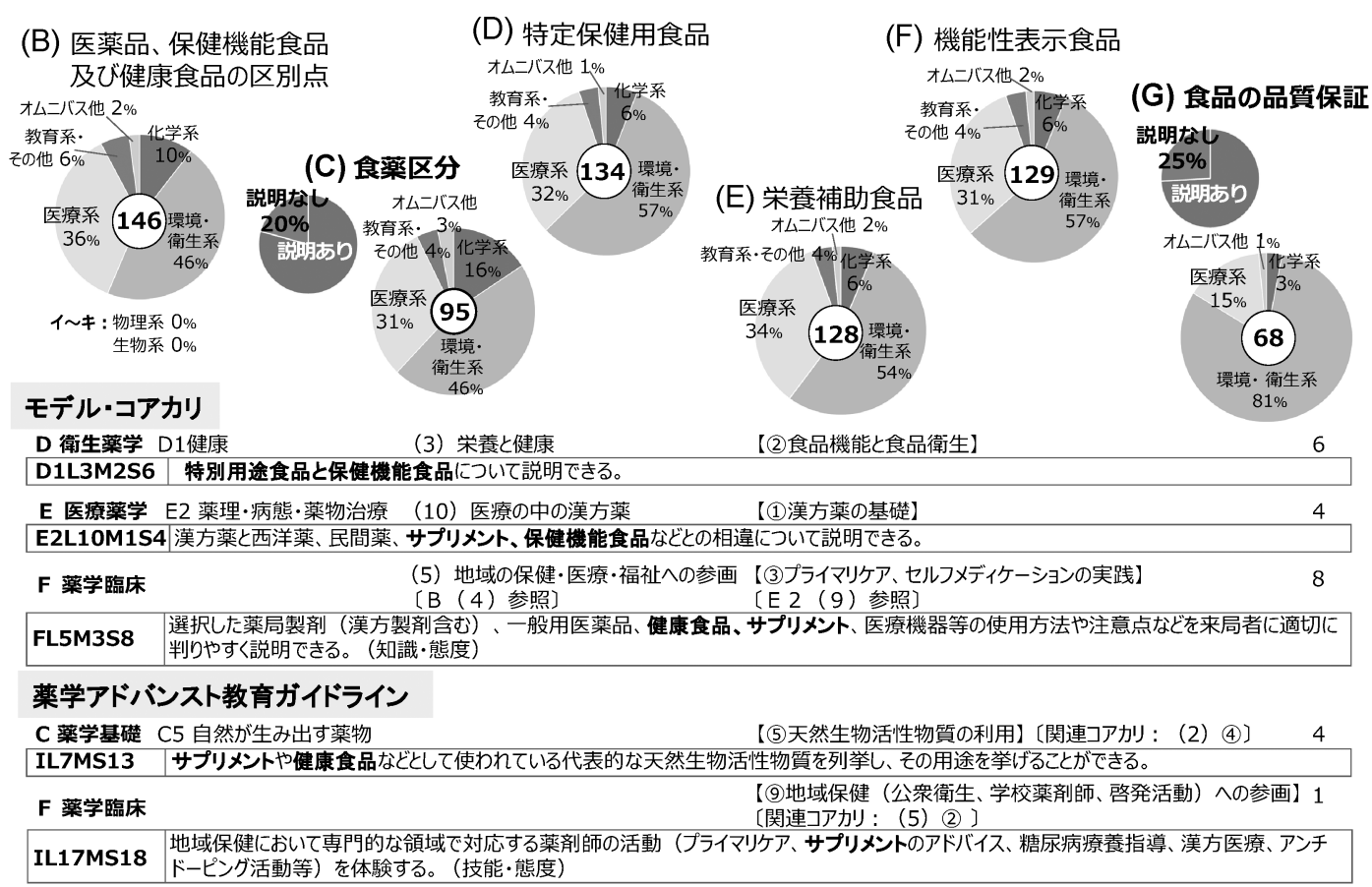

Fig. 12. Relevance of the Survey Results to Contents of the Model Core Curriculum for Pharmaceutical Education 2

(B) Distinguishing features of pharmaceuticals, foods with health claims and so-called "health food"; (C) Borderline of pharmaceuticals to non-pharmaceuticals; (D) Foods for specified health uses; (E) Foods with nutrient function claims; (F) Foods with function claims; (G) Quality assurance of foods.

(H) 品質の定義
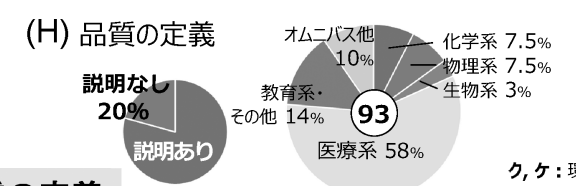

ク,ケ : 環境·衛生系 $0 \%$
(I) 品質保証とは

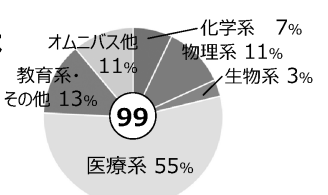

モデル・コアカリ

B 薬学と社会

（2）薬郕師と医薬品等に係る法規範【(2)医薬品等の品質、有効性及び安全性の確保に係る法規範】7 BL2M2S07|医薬品等の取扱いに関する「医贾品、医謤機器等の品質、有効性及び安全性の確保等に関する法律」の規定について説明できる。

\begin{tabular}{|c|c|c|}
\hline C 薬学基礎 C5自然が生み出す薬物 （1）薬になる動植鉱物 & 【(4)生薬の同定と品質評価】 & 1 \\
\hline C5L1M4S1|生薬の同定と品質評価法について概説できる。 & & \\
\hline$E$ 医療薬学 $E 3$ 薬物治療に役立つ情報 $\quad(1 ）$ 医薬品情報 & 【(7)医薬品の比較·評価】 & 3 \\
\hline
\end{tabular}

間接的 E3L1M7S3 医薬品情報にもとどいて、先発医薬品と後発医薬品の品質、安全性、経済性などについて、比較·評価できる。(技能)

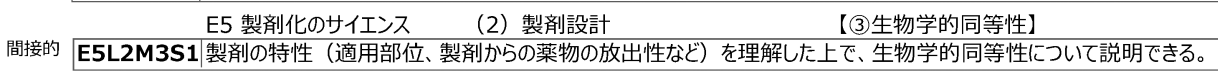

(I) 品質保証とは

薬学アドバンスト教育ガイドライン B 薬学と社会

【(2医薬品等の品質、有効性及び安全性の確保に係る法規範】 [関連马アかリ：(2) (2) ] \begin{tabular}{|l|l|l} 
IL2MS1 & レギュラトリーサイエンスに基づく医蓃品等の品質、有効性及び安全性の評価法について説明できる。 \\
\hline
\end{tabular}

C 薬学基礎 C5 自然が生み出す薬物

【(3)生薬の同定と品質評価】関連コアかリ：(1) (4)]

間接的 IL7MS5 1 代表的な生薬の確認試験を実施できる(技能)

【(1)製剤化〕〔関連コアかり：

(2) (2)]

$E$ 医療薬学 E5 製刘化のサイエンス

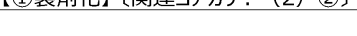

$F$ 薬学臨床

【(2医薬品の供給と管理】〔関連つアかり：（2）(5)

間接的 IL17MS6 調製した製剤の品質試験を体験する。(技能、態度)

*間接的に関わってくると考えられる項目

Fig. 13. Relevance of the Survey Results to Contents of the Model Core Curriculum for Pharmaceutical Education 3 (H) Definition of quality; (I) Quality assurance. 
(J) 医薬品の区分

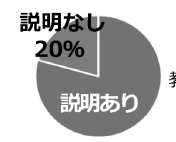

\section{(J) 医薬品の区分}

モデル・コアカリ

$B$ 薬学と社会

BL2M2S01

$F$ 薬学臨床

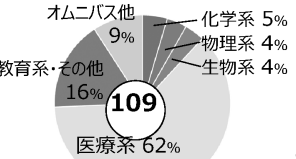

（K）医薬品の承認申請

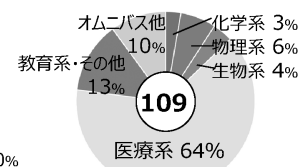

医療系 $64 \%$

コ, サ : 環境·衛生系 0\%

（2）薬剤師と医薬品等に係る法規範【【2医薬品等の品質、有効性及び安全性の確保に係る法規範】1 薬事法) の目的及び医薬品等（医菜品、医薬部外品、化粧品、医療機器）の定義について説明できる。

\begin{tabular}{|c|c|c|}
\hline & & 〔E 2 (9) 参照〕〔関連つアかリ \\
\hline 接的 & FL5M3S3 & 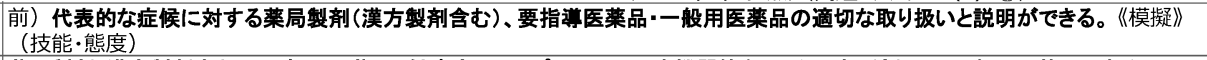 \\
\hline 成接的 & FL5M3S5 & $\begin{array}{l}\text { 薬局製剤(漢方製剂含む)、一般用医薬品、健康食品、サプリメント、医療機器等をリスクに応じ適切に取り扱い、管理できる。 } \\
\text { (技能·態度) }\end{array}$ \\
\hline 接的 & FL5M3S8 & 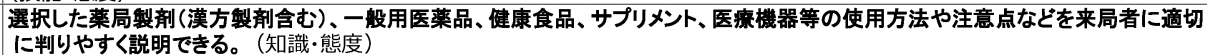 \\
\hline
\end{tabular}

\section{（K）医薬品の承認申請}

モデル・コアカリ

B 薬学と社会 （2）薬剤師と医薬品等に係る法規範 【(2医薬品等の品質、有効性及び安全性の確保に係る法規範】2 BL2M2S02 医薬品の開発から承認までのプロセスと法規範について概説できる。

薬学アドバンスト教育ガイドラインガイドライン

B 薬学と社会

IL2MS4

【(3)医薬品と医療の経済性】〔関連コアかリ：(3) (2)

Fig. 14. Relevance of the Survey Results to Contents of the Model Core Curriculum for Pharmaceutical Education 4 (J) Classification of pharmaceuticals; (K) Marketing authorization process of pharmaceuticals.

(L) $\mathrm{ICH}$

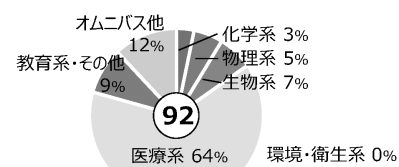

(M) $\mathrm{CMC}$

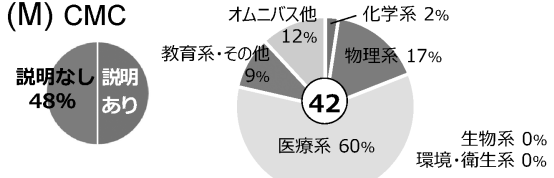

\section{(L) ICH (医薬品規制調和国際会議)}

\section{薬学アドハシンスト教育ガイドライン}

$B$ 菜学と社会

【(2)医薬品等の品質、有効性及び安全性の確保に係る法規範】

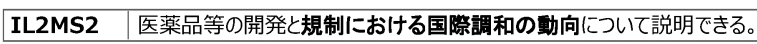

B 薬学と社会 〔関連コア炒：(2) (2)]

2

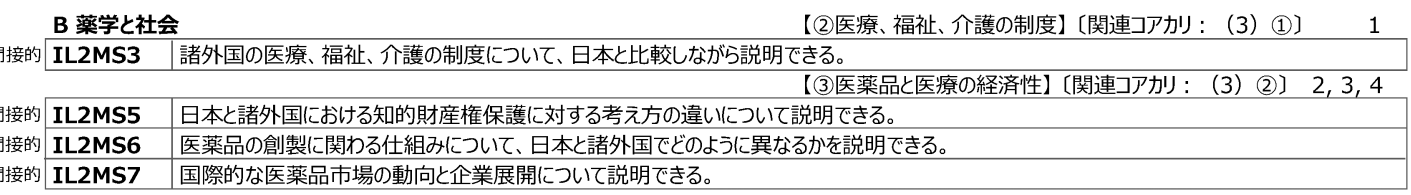

\section{(M) CMC (化学、製造、管理)}

\section{モデル・コアカリ}

\section{B 薬学と社会}

（2）薬剤師と医薬品等に係る法規範 【(2医薬品等の品質、有効性及び安全性の確保に係る法規範】4 BL2M2S04|医薬品等の製造販売及び製造に係る法規範について説明できる。

\begin{tabular}{|c|c|c|c|}
\hline$F$ 薬学臨床 & （2）処方せんに基づく調剤 & 【(5)医薬品の供給と管理】 & 6,8 \\
\hline
\end{tabular}

間接的 FL2M5S06 前) 院内製剤の意義、調製上の手続き、品質管理などについて説明できる。

間接的 FL2M5S08 前) 医薬品の品質に影響を与える因子と保存条件を説明できる。

\section{薬学アドバンスト教育ガイドライン}

$F$ 薬学臨床

間接的 IL17MS6

【(2)医薬品の供給と管理】関連コアかリ：(2) (5)〕 3

Fig. 15. Relevance of the Survey Results to Contents of the Model Core Curriculum for Pharmaceutical Education 5

(L) International Council for Harmonisation of Technical Requirements for Pharmaceuticals for Human Use; (M) Chemistry, Manufacturing and Control. 
をモデル・コアカリへ収載することを希望する. $(\mathrm{J})$ 医薬品の区分については，モデル・コアカリの B (2) (2)の 1 項に「医薬品・医療機器法の目的及び医 薬品等の定義について説明できる」とあり，F（5） 地域の保健・医療・福祉への参画【(3)プライマリケ ア，セルフメディケーションの実践】の $3,5,8$ 項 では薬局製剤，要指示医薬品・一般用医薬品，健康 食品, サプリメント，医療機器等の適切な取扱いと 説明，管理が求められおり，薬剤師として理解し， 実践しなければならない事項である（Fig. 14）。し かし，20\%の大学で説明されていなかったことか ら，改善が必要である。（L) ICH はモデル・コア カリに記載がなかったが，アドバンスト教育ガイド ラインの B(2)の 2 項に「医薬品等の開発と規制にお ける国際調和の動向について説明できる」とあり, これに関連して ICH の内容が説明されているよう であった。（M） CMC は，モデル・コアカリの B (2) (2)の 4 項の「医薬品等の製造販売及び製造に係 る法規範について説明できる」などに関連する (Fig. 15)。医薬品開発（非臨床試験から臨床試験） や医薬品製造に必要な情報の管理は製薬業界が必要 としている基本的内容であり, 医療系薬学, 教育系 薬学・その他, 物理系薬学の科目で説明されるべき 内容であるが, 約半数の大学で教えられていなかつ た． CMC は，製造物としての薬の品質評価を統合 する概念であり，実社会での応用力を育てる薬学教 育ではおろそかにしてはいけない内容であり，教育 の改善が求められる.

\section{4. まとめ}

現在の薬学教育では，医療を担う薬学の根幹をな すと考えられる「品質の定義」と「品質保証」の教 育が十分ではない傾向にあった。この点を改善し て，医薬品の品質保証に関する概念が薬学生に定着 すれば，レギュラトリーサイエンスの必要性も自ず と理解されるであろう。また，保健機能食品や健康 食品の品質保証への応用も期待できる．これを定着 させない限り，薬学分野で目標の 1 つとされている 医薬品や食品を用いたプライマリヘルスケアやセル フメディケーションは, わが国の健康・医療におい て十分に効果を発揮しないと考えられる.

生薬は医薬品として使用されるほか，機能性表示 食品や健康食品の原料として用いられることも多 い．グローバル化した今日，外国産生薬の健康産業
への応用が増えることが予想されることから，生薬 の化学的な品質保証を基盤とした保健機能食品等の 品質保証はますます重要になるであろう。また，医 薬品及び保健機能食品が目標とする品質規格を決定 する際には，有効性及び安全性を科学的に証明する ための薬理学的研究が不可欠となる. したがって, 品質の規格審査において薬理活性に基づく品質保証 も重要である。ささに，多くの保健機能食品は製剤 化されて製品となる。したがって，食品であったと しても，医薬品と同様，製剂学的な品質保証が不可 欠である. 今回のアンケート調査で取り上げた医薬 品の品質保証，医薬品の承認申請， $\mathrm{CMC}, \mathrm{ICH}$ は 一連の流れの下で成立するものであり，一貫した教 育が必要であると考えられるが，現状ではこれを実 施できている大学は少なかった。

以上，今回の調査により，食品・医薬品の品質保 証に関する薬学教育の実態が明らかになった。質問 で提示した重要項目に関して，不足している点を認 識しながら薬学の各学系から教育を実施して頂き, プライマリヘルスケアやセルフメディケーション等 を含めた健康と医療を支える薬学分野の人材を育成 して頂けることを切望する，また，品質保証は，医 薬品の開発，承認申請，製造にとつても重要で，そ の応用範囲は広いことから，品質の定義とともに低 学年から複数科目で教育すると効果的であるとも考 えられる。

謝辞本稿は, 日本学術会議薬学委員会医療系 薬学分科会（24 期）の企画の下，2019 年に全国薬 科大学長・薬学部長のご理解とご協力を賜り, 全国 の薬学部を設置する 75 大学を対象に行ったアン ケート調査の結果をまとめたものです。ご協力を賜 りました全国の薬科大学長及び薬学部長に深甚なる 謝意を表します。また，本アンケート調査は同分科 会会員の国立医薬品食品衛生研究所 合田幸広所長 を中心として, 静岡県立大学薬学部 黒川洵子教 授, 京都大学大学院薬学研究科 伊藤美千穂准教授 及び大阪大学大学院薬学研究科 堤 康央教授とと もに実施し，取りまとめを行いました。ここに記し て心より感謝申し上げます。

利益相反＼cjkstart開示すべき利益相反はない. 


\section{REFERENCES}

1) Science Council of Japan, “The report: Promotion of Social Contributions of Research on Clinical Pharmacy and Pharmaceutical Sciences," September 29, 2017, p. 9: 〈http:// www.scj.go.jp/ja/info/kohyo/2017.html〉, cited 25 August, 2020.

2) Ministry of Education, Culture, Sports, Science and Technology (MEXT), "Model Core Curriculum for Pharmacy Education," revised edition, 2013: 〈https://www.mext.go. jp / component / a_menu / education / detail / __icsFiles / afieldfile / 2015 / $02 / 12$ / 1355030 01.pdf $\rangle$, cited 25 August, 2020.
3) Ministry of Education, Culture, Sports, Science and Technology (MEXT), "Model Core Curriculum for Pharmacy Education," revised edition, 2013: 〈https://www.mext.go. jp / component / a_menu / education / detail / __icsFiles/afieldfile/2015/02/12/1355030_02. pdf $\rangle$, cited 25 August, 2020.

4) Ministry of Education, Culture, Sports, Science and Technology (MEXT), "Model Core Curriculum for Pharmacy Education," revised edition, 2013: 〈https://www.mext.go. jp / component / a_menu / education / detail / __icsFiles/afieldfile/2015/02/12/1355030_03. pdf $\rangle$, cited 25 August, 2020. 